\title{
How Does Destination Social Responsibility Impact Residents' Pro-Tourism Behaviors? The Mediating Role of Place Attachment
}

\author{
Bing $\mathrm{Hu}^{1}$, Yangying Tuou ${ }^{1}$ and Jing Liu ${ }^{2, *}$ \\ 1 College of Tourism, Hunan Normal University, Changsha 410081, China; bing@whu.edu.cn (B.H.); \\ bh0114@163.com (Y.T.) \\ 2 Faculty of Hospitality and Tourism Management, Macau University of Science and Technology, \\ Macau 999078, China \\ * Correspondence: gloria.liu@okstate.edu
}

Received: 12 April 2019; Accepted: 14 June 2019; Published: 18 June 2019

\begin{abstract}
There has been little research on how destination social responsibility impacts the pro-tourism behaviors of residents. Drawing from place attachment theory and sustainable tourism literature, this study proposes that place attachment mediates the link between destination social responsibility and pro-tourism behaviors. The results from a field survey of local residents around three scenic spots in the Xuefeng mountain area in China reveal that destination social responsibility exerts a significantly positive impact on pro-tourism behaviors of residents, and confirm a mediating effect of place attachment (i.e., place identity and place dependence) in the linkage of destination social responsibility and pro-tourism behaviors. This research provides theoretical and managerial contributions to sustainable tourism literature and advances the understanding of the antecedents of residents' pro-tourism behaviors.
\end{abstract}

Keywords: destination social responsibility; place attachment; pro-tourism behaviors; residents

\section{Introduction}

Destination environments and communities are the indispensable compositions of the tourism industry and integrated parts of tourism products. Destination residents exert an increasing impact on the destination's environment and tourism products because of their everyday living activities within the community, as well as growing face-to-face interaction in tourism activities. Destination residents' behaviors impact tourists' traveling activities in all aspects, from traveling information search [1] to tourism product consumption [2]. The principles of sustainable tourism development should give equal weight to local resident attitudes and tourist tastes [3], since destination residents' support for tourism development, likewise residents' participation in environmentally responsible behavior, is considerable to ensure sustainability in tourism development [4]. Destination residents' pro-tourism behaviors can be a precondition for sustainable tourism [5].

In the search for additional levers to motivate residents' pro-tourism behaviors, some tourism companies and governments have turned to social responsibility initiatives. In China, tourism companies have been increasingly engaged in destination social responsibility, such as the protection of the ecological environment, conservation of culture and heritage, employee volunteerism programs, corporate philanthropy, pro-poor tourism, and sustainable tourism. Moreover, the Chinese government is encouraging tourism companies to participate in targeted poverty alleviation through tourism development. Thus, research like this is desirable to enhance the understanding of whether social responsibility initiatives perceived by residents within the destination community can impact their pro-tourism behaviors. 
Studies investigating predictors of residents' pro-tourism behaviors have been well-documented, such as perceived personal economic benefit [6], the state of the local economy [7], resident empowerment [8], tourism impact [9], environmental quality, and eco-friendly reputation [10]. Despite these efforts, the exploration into residents' pro-tourism behaviors has two major research gaps. First, few studies explored the antecedents of residents' pro-tourism behaviors from the perspective of social responsibility, in particular, focused on the effect of destination social responsibility on residents' pro-tourism behaviors. Second, although Su et al. [11] developed a social exchange model relating destination social responsibility with local residents' responsible behavior, the psychological people-place bonding mechanism linking destination social responsibility to pro-tourism behaviors, however, remains unclear.

Considering the currently ignored linkage in tourism literature, we developed a model that highlights the role of residents' psychological mechanism in the effect of destination social responsibility on pro-tourism behaviors. In particular, drawing upon place attachment theory, this research intends to (a) test the direct influence of destination social responsibility on residents' pro-tourism behaviors in China, an under-examined but increasingly important context and (b) investigate the mediating role of residents' place attachment (i.e., place identity and place dependence) through which destination social responsibility affects their pro-tourism behaviors.

This research contributes to the place attachment theory and tourism literature streams in multiple aspects. First, our study is among the first to develop a model that links destination social responsibility to residents' pro-tourism behaviors, which adds to the knowledge of determinants of residents' pro-tourism behaviors. Second, our research identifies the route of psychological people-place bonding through which destination social responsibility is related to residents' pro-tourism behaviors. This study diverts from the conventional social exchange perspective that largely identifies pro-tourism behaviors as attempts to maximize positive tourism impact. We propose that residents' pro-tourism behaviors can also be determined by psychological bonding between residents and their meaningful environments. In addition, this study also contributes to guidelines for strategic and operational management practices for both tourism companies and administrations to motivate residents' pro-tourism behaviors.

This study is organized as follows: First, the literature review section outlines previous research progress of destination social responsibility, place attachment (i.e., place identity and place dependence), and residents' pro-tourism behaviors, and then develops the hypotheses and conceptual model. The methodology section introduces the method context, including the sample and data, construct measurement, and data analysis method, which are applied to examine the proposed model. The final two sections show research results and conclude with a general discussion of theoretical and managerial implications, limitations, and directions for future research.

\section{Literature Review and Hypotheses Development}

\subsection{Residents' Pro-Tourism Behaviors}

Sustainable tourism is a win-win strategy [12], not only for protecting the environment, conserving the ecological and sociocultural integrity, and protecting natural and cultural heritage but also for meeting human needs, such as providing tangible economic benefits and improving residents' quality of life [13]. An increasing number of studies suggest that sustainable tourism shows a challenging issue for future tourism development. Some scholars suggest that sustainable tourism development should not only concentrate on tourist tastes but also give weight to local residents' attitudes and behaviors [3], given that destination residents' support for tourism development and participation in environmentally responsible behavior are considered to ensure sustainability in tourism development [4]. Destination residents' pro-tourism behaviors can be a precondition for sustainable tourism [5].

Residents' pro-tourism behavior, which can be defined as destination residents' support for tourism development (e.g., be more hospitable to tourists) and residents' participation in environmentally responsible behavior (e.g., protect the environmental and natural resources), is a considerable issue, 
ensuring sustainability in tourism development [4]. Destination residents' pro-tourism behaviors can be a significant precondition, impacting the sustainability of any destination $[5,14]$. Destination residents' involvement and behaviors impact tourists' traveling perceptions and experiences at all aspects, from traveling information search [1] to tourism product consumption [2], through residents' everyday living activities within the community and the growing person-to-person interactions in tourism activities.

What can motivate residents' pro-tourism behaviors? Overall, there are two research streams considering the predictors of residents' pro-tourism behaviors. First, the social exchange theory has been extensively utilized as a conceptual framework in explaining residents' pro-tourism behaviors [14-16]. In this perspective, the pro-tourism behaviors of residents can be attributed to economic factors, such as the perceived personal economic benefit [6], the assessment of economic, sociocultural, psychosocial, and environmental tourism effects [9], the tradeoff of positive and negative tourism impacts [16], etc. Second, the predictors of residents' pro-tourism behaviors may also be ascribed to non-economic factors, such as resident empowerment (i.e., the psychological, social, and political empowerment) [8], host-tourist interaction [15], and environmental quality and eco-friendly reputation [10].

\subsection{Destination Social Responsibility and Pro-Tourism Behaviors}

Corporate social responsibility (CSR) describes firms' discretionary business initiatives that improve societal well-being beyond that which is commanded by law [17,18]. Recently, studies exploring CSR initiatives in the tourism context have emerged and been applied to various tourism-related industries, such as the airline industry [19], the cruise industry [20], the restaurant context [21-23], the casino industry $[24,25]$, the hotel industry [26,27], and the tourism-related contexts (i.e., airlines, hotels, restaurants, and casinos) [28,29]. However, the assessment of CSR in the destination context (destination social responsibility) may vary from the previous traditional CSR research. The service providers in a destination may be comprised of various tourism-related operators, such as airlines, restaurants, hotels, travel agencies, ground transportation, etc. Therefore, in the destination context, the perceptions of CSR can be the consequences of the collective actions of all tourism-related operators within a community. In our study, we adopt the distinctive concept of destination social responsibility as "the collective philosophy and initiatives of destination stakeholders to engage in socially responsible activities as perceived by destination residents" [11].

Why does destination social responsibility affect the pro-tourism behaviors of residents? First, the social exchange theory provides some explanatory evidence to this link. As core stakeholders, community residents can benefit from destination social responsibility initiatives, ranging from protection of the ecological environment, conservation of culture and heritage, corporate philanthropy to pro-poor tourism, and targeted poverty alleviation that invests in responsibility/sustainability, all which ultimately improve quality of life and promote societal welfare of community residents. According to social exchange theory, when residents are exposed to destination social responsibility initiatives, they may support tourism development, as well as become involved in environmentally responsible behavior as a demonstration of appreciation and reciprocity [16]. Therefore, social exchange theory can be used to provide a theoretical foundation for destination social responsibility initiatives, effectively motivating residents to participate in pro-tourism behaviors.

Second, many tourism research streams and indirect evidence have addressed this link. For example, the empirical results from Su et al. [10] indicated that destination environmental quality exerts an influence on residents' environmentally responsible behavior. Furthermore, Su et al. [11] also found that there remains an indirect link between destination social responsibility and residents' support for tourism. On the basis of the stakeholder theory, firms leverage CSR activities to exert an impact on various stakeholders, including tourists, employees, and community residents [30]. The extant tourism CSR research has started to consider CSR actions primarily as connections to shareholders' values [22,29], customers' behavior [31,32], employee-associated outcomes [25,26], and residents' attitudes and support [11,16]. 
Therefore, the following hypothesized relationship is proposed:

Hypothesis 1 (H1). Destination social responsibility is positively associated with pro-tourism behaviors of residents.

\subsection{Destination Social Responsibility and Place Attachment}

Place attachment theory, which describes "an interplay of affect and emotions, knowledge and beliefs, and behaviors and actions" [33] between people and a particular place, provides an adequate explanation perspective, linking destination social responsibility to pro-tourism behaviors of residents. Place attachment theory not only has aroused great interest among humanistic geographers and sociologists who have worked on the development of place attachment theory [34] but also has attracted much attention from tourism researchers focused on its applicability for interpreting behaviors by residents and tourists [4]. Place attachment, "the phenomena of people-place bonding" [33], can be defined as a positive emotional linkage to particular locations, settings, or environments, typically incorporating both physical and social components [35,36].

While varying measures of place attachment have been applied across many studies, the two-dimensional place attachment model, including place dependence and identity, has been extensively adopted in environmental psychology and tourism literature [37-39]. The two-dimensional model not only allows researchers to distinguish between instrumental and affective people-place bonding [40] and embrace emotional connection as well as the goal-facilitating of the construct [37] but also ensures the reliability and validity of the research $[33,41]$.

The current research adopts the two-dimensional model that breaks down place attachment into (1) place dependence (related to the functional bonds with a place) and (2) place identity (related to the affective or symbolic connections to a place). Place dependence involves the functional or goal-oriented bonding that people have with places based specifically on physical features and settings of a place, which provide conditions to support certain activities [41,42]. While place identity describes the symbolic connections and meanings given to a place that defines who we are [43] and depicts how physical and symbolic characteristics of places are embodied in people's broader self-identity [36]. Place identity arises from the ideas, experiences, memories, and feelings connected with a place $[37,43,44]$.

Place attachment emerging through individual perception and experience with specific places and their meaningful environments can be affected by environmental qualities, cultural values, mobility, and recreational chances [45]. In particular, place attachment is closely bound up with the social responsibility and sustainability of a place. It requires effort and dedication to preserve the physical environment of a place, protection of ecosystems, history, culture, and community [46], as well as a financial guarantee, social cohesion, and control [47].

Previous studies indicated that destination environmental condition and eco-friendly image and reputation have a direct impact on environmental identification and community commitment of residents [10]. Therefore, through destination social responsibility initiatives, such as protection of the ecological environment, conservation of culture and heritage, and pro-poor tourism and targeted poverty alleviation, that invest in responsibility/sustainability, this people-place psychological connection of residents can be activated. Moreover, the marketing literature stream also demonstrates that social responsibility communicates the underlying cultural values of the organization, which could lead people to form a strong psychological bond with the organization itself [17].

In sum, all these arguments imply that destination social responsibility may help promote place dependence and place identity of residents. Therefore, we present the following hypothesized relationship:

Hypothesis 2 (H2). Destination social responsibility is positively related to place dependence of residents.

Hypothesis 3 (H3). Destination social responsibility is positively related to place identity of residents. 


\subsection{The Mediating Effect of Place Attachment}

The existing environmental psychology and tourism literature demonstrate accumulating evidence for the influence of place attachment (i.e., place identity and place dependence) on pro-tourism behaviors of residents [48-50]. Specifically, place dependence and place identity have been demonstrated to impact various aspects of the pro-tourism behaviors of residents, such as residents' experiences of psychological empowerment and social empowerment via tourism development [51], environmentally responsible behavior (ERB) [44], destination brand-building behaviors (word of mouth, ambassador behavior, leaving intention, and involvement in tourism planning and development, social responsible behaviors, etc.) [4], and community residents' attitudes towards tourism in island destinations [15].

In linking this evidence for the impact of place attachment (i.e., place identity and place dependence) on residents' pro-tourism behaviors with our second and third hypotheses on the impact of destination social responsibility on place identity and place dependence, a mediating role of place attachment on the destination social responsibility and pro-tourism behaviors linkage might logically be expected. That is, destination social responsibility can exert an influence on place attachment, which, in turn, impacts pro-tourism behaviors of residents. Namely, place attachment shows the mediational pathway through which destination social responsibility impacts pro-tourism behaviors.

Consequently, putting the above arguments together, our research predicts a mediating effect of place attachment (i.e., place identity and place dependence) on the linkage of destination social responsibility and pro-tourism behaviors of residents.

Hypothesis 4 (H4). Place dependence mediates the effect of destination social responsibility on pro-tourism behaviors of residents.

Hypothesis 5 (H5). Place identity mediates the effect of destination social responsibility on pro-tourism behaviors of residents.

Based on the above arguments and hypotheses, the following conceptual framework among the links between destination social responsibility, place dependence, place identity, and pro-tourism behaviors of residents is presented (see Figure 1).

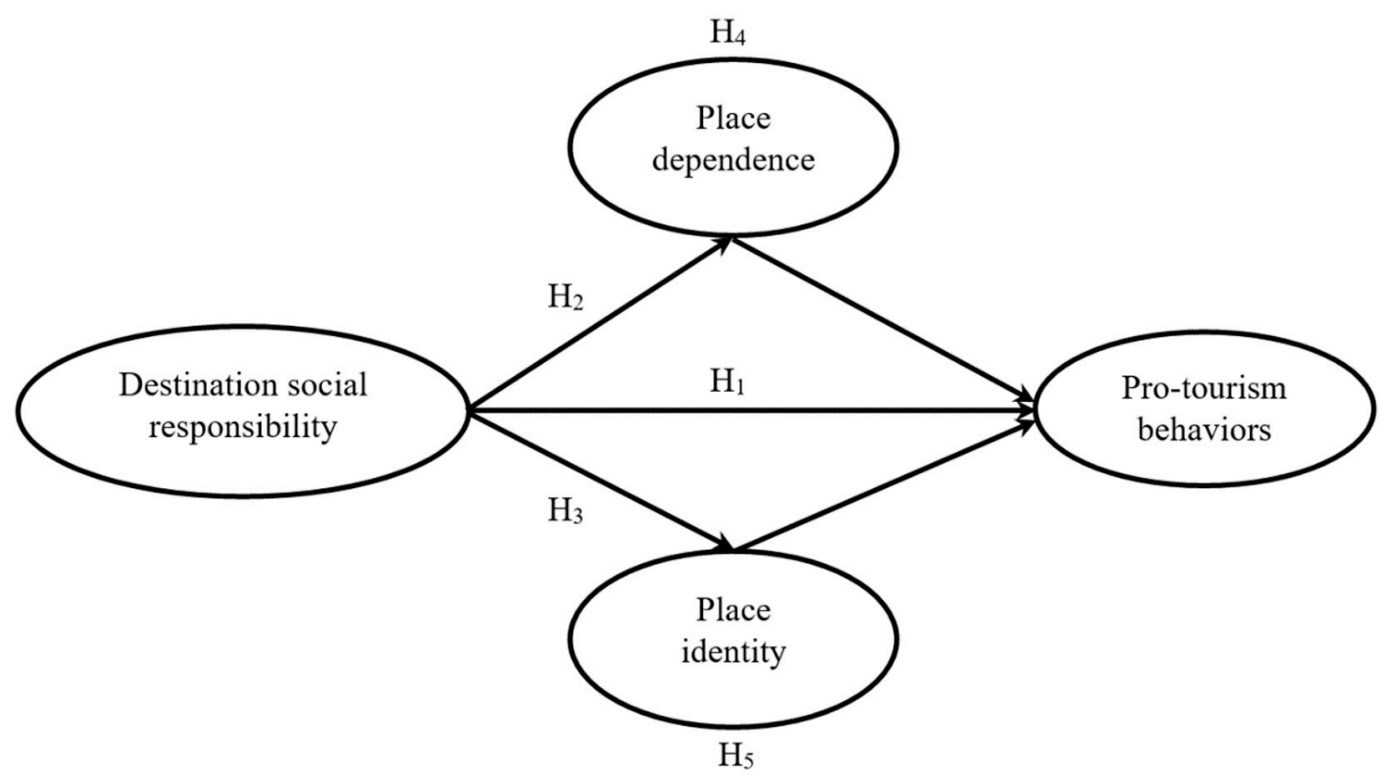

Figure 1. The proposed conceptual model. 


\section{Methodology}

\subsection{Sample and Data}

We conducted a convenience sampling approach and chose the residents living in the Xuefeng mountain area of China as our respondents. The self-administered questionnaires were distributed to local community residents in the Xuefeng mountain area who live around the three scenic spots, namely, Huayao Terrace, Chuanyan mountain forest park, and the ancient village Yangquepo. These scenic spots are famous for their heritage tourism, rural tourism, and unique natural scenery and attract a large number of tourists every year. These scenic spots have been engaged in the protection of ecological culture, development of rural tourism, and poverty alleviation, as well as providing jobs for local farmers to increase their income and wealth in the Xuefeng mountain area. The survey lasted 2 weeks from 28 September 2018 to 12 October 2018. Six trained research assistants were organized into three groups to distribute the questionnaires in the villages around the three scenic spots in the Xuefeng mountain area. A total of 450 questionnaires were distributed, and 433 questionnaires were returned to our research assistants. After eliminating incomplete questionnaires, 381 usable questionnaires were collected and used for further analysis, resulting in a response rate of approximately $84.67 \%$.

Respondents' demographic characteristics are shown in Table 1 . The respondents were $58.79 \%$ male and $41.21 \%$ female. Most of the respondents were in the $25-44$ age and $45-64$ age range $(42 \%$, $38.05 \%$, respectively). A majority of the respondents had a junior or senior high school level of education, with only $0.26 \%$ having a postgraduate degree. The respondents had a balanced ratio of tourism-related jobs $(48.82 \%)$ and no tourism-related jobs $(51.18 \%)$.

Table 1. The demographic characteristics of the sample.

\begin{tabular}{|c|c|c|}
\hline Demographic & $\mathbf{N}$ & $\%$ \\
\hline \multicolumn{3}{|l|}{ Gender } \\
\hline Male & 224 & 58.79 \\
\hline Female & 157 & 41.21 \\
\hline \multicolumn{3}{|l|}{ Age } \\
\hline 18 to 24 & 39 & 10.24 \\
\hline 25 to 44 & 160 & 42.00 \\
\hline 45 to 64 & 145 & 38.05 \\
\hline 65 or Older & 37 & 9.71 \\
\hline \multicolumn{3}{|l|}{ Education } \\
\hline Junior High School or Below & 160 & 41.99 \\
\hline Senior High School & 156 & 40.94 \\
\hline Undergraduate/Associate Degree & 64 & 16.80 \\
\hline Postgraduate Degree or Above & 1 & 0.26 \\
\hline \multicolumn{3}{|l|}{$J o b$} \\
\hline Tourism-related job & 186 & 48.82 \\
\hline No tourism-related job & 195 & 51.18 \\
\hline
\end{tabular}

\subsection{Construct Measurement}

The self-administered questionnaire was comprised of three constructs: pro-tourism behaviors, destination social responsibility, and place attachment. In addition, the construct for place attachment included two dimensions: place dependence and place identity. A 7-point Likert scale was utilized in this survey, which ranged from 1 (strongly disagree) to 7 (strongly agree). According to the back-translation procedure [52], the items for this research were adapted from previously published scales in English to ensure they are appropriate for destination residents with a Chinese background. 
Pro-tourism behaviors. To measure residents' pro-tourism behaviors, we adopted a 5-item scale adapted from Ribeiro et al. [14]. Sample items included "I would protect the natural resources on which tourism depends".

Destination social responsibility. The measurement of destination social responsibility in our study was adapted from the research of Su et al. [11], which was drawn from previous CSR studies. The 5-item scale of destination social responsibility captures the environmental, economic, social, stakeholder, and discretionary dimensions (e.g., "The scenic spot at the Xuefeng Mountain appears to include environmental issues in its management") with demonstrated reliability and validity [16].

Place attachment. The construct of place attachment with 8 items was adapted from the studies of Raymond et al. [42] and Williams and Vaske [37]. It is comprised of two dimensions: place dependence with 4 items (e.g., "There is no substitute for the activities I prefer in Xuefeng Mountain") and place identity with 4 items (e.g., "I identify strongly with Xuefeng Mountain").

\subsection{Data Analysis Method}

To examine the conceptual framework, we employed a two-stage data analysis method. This study first conducted the confirmatory factor analysis (CFA) to assess the validity and reliability of the measurement instrument. The second procedure intended to test the hypothesized inter-variable relationships. In particular, our study utilized structural equation modeling (SEM) to evaluate the appropriateness of the conceptual model and test the hypothesized direct links among destination social responsibility, place dependence, place identity, and pro-tourism behaviors of residents. Moreover, to estimate the extent to which place attachment (i.e., place identity and place dependence) explained the indirect relationship between destination social responsibility and pro-tourism behaviors of residents, our study conducted Sobel tests [53] and bootstrapping tests [54].

\section{Empirical Results}

\subsection{Common Method Variance Checking}

A self-administered survey may result in a potential biasing problem on the measurement of constructs [55]. It is desirable to conduct both procedural remedies and statistical control techniques to minimize such biasing effects. Therefore, a few procedural steps in this study were first conducted, such as the design of reversed items and assurance of respondent anonymity. In addition, a pilot study of the instrument was conducted to further ensure the conciseness. The questionnaire was distributed to a small group of residents in the Xuefeng mountain area for the pilot test $(\mathrm{N}=95)$, and the errors of two items were corrected based on the feedback from the pilot test results.

Moreover, statistical control techniques were conducted in this study. The Harman's single-factor test was utilized by importing all four constructs into a principal component factor analysis. Using STATA 15, we utilized an exploratory factor analysis (EFA) to investigate the covariation of each factor. Exploratory factor analysis results indicated that each factor occupied less than $50 \%$ of the covariation, which shows no evidence of a problem of common method bias [55]. In addition, confirmatory factor analysis results also showed that a one-factor model did not fit the data well $\left(X^{2}=1873.16 ; \mathrm{df}=170\right.$; $\left.p<0.001, X^{2} / \mathrm{df}=11.019, \mathrm{TLI}=0.754, \mathrm{CFI}=0.780, \mathrm{SRMR}=0.056, \mathrm{RMSEA}=0.155\right)$, which further confirms that common method bias is not a severity in our study.

\subsection{Measurement Model Results}

\subsubsection{Measurement Model Indices}

Confirmatory factor analysis (CFA) was conducted to check the fit between the model and data. The model fit indices, e.g., Tucker-Lewis coefficient (TLI), comparative-fit index (CFI), root mean square error of approximation (RMSEA), and standardized root mean square residual (SRMR), were selected for measurement model fit check. CFA results revealed that the fitting indices were acceptable $\left(X^{2}=\right.$ 
284.874, $\left.\mathrm{df}=108, p<0.001, X^{2} / \mathrm{df}=2.641, \mathrm{TLI}=0.924, \mathrm{CFI}=0.946, \mathrm{SRMR}=0.060, \mathrm{RMSEA}=0.066\right)$, which indicates that the measurement model fits the data well.

\subsubsection{Reliability Testing}

This study utilized the Cronbach's $\alpha$ and the composite reliability (CR) to check the measure of scale reliability. Table 2 presents the Cronbach's $\alpha$ results for each factor, showing that the Cronbach's $\alpha$ of each factor ranged from 0.788 to 0.844 , exceeding 0.700 and indicating that the scale of each factor achieved adequate internal consistency [56]. In addition, Table 3 shows the composite reliability results for each factor, which ranged from 0.816 to 0.860 , exceeding the threshold (0.7) suggested by Hair et al. (2006), and indicating well construct reliability.

Table 2. Measurement model results.

\begin{tabular}{|c|c|c|c|c|}
\hline Constructs and Items & Mean & SD & Factor Loading & Cronbach's $\alpha$ \\
\hline Destination social responsibility & & & & 0.792 \\
\hline \multicolumn{5}{|l|}{ The scenic spot at the Xuefeng Mountain: } \\
\hline $\begin{array}{l}\text { appears to include environmental issues in its } \\
\text { management }\end{array}$ & 6.218 & 0.958 & 0.724 & \\
\hline appears to donate to the local community & 5.858 & 1.006 & 0.753 & \\
\hline appears to be profitable & 5.743 & 0.996 & 0.685 & \\
\hline appears to treat its stakeholders well & 5.693 & 1.007 & 0.646 & \\
\hline appears to act ethically and beyond all legal obligations & 5.945 & 0.962 & 0.748 & \\
\hline Place dependence & & & & 0.812 \\
\hline Xuefeng Mountain is my favorite place to be & 5.635 & 1.011 & 0.662 & \\
\hline $\begin{array}{l}\text { I get more satisfaction from Xuefeng Mountain than } \\
\text { other places }\end{array}$ & 5.664 & 1.072 & 0.759 & \\
\hline $\begin{array}{l}\text { I prefer Xuefeng Mountain to others for the activities } \\
\text { that I enjoy }\end{array}$ & 5.842 & 1.006 & 0.750 & \\
\hline $\begin{array}{l}\text { There is no substitute for the activities I prefer in } \\
\text { Xuefeng Mountain }\end{array}$ & 5.816 & 1.089 & 0.727 & \\
\hline Place identity & & & & 0.844 \\
\hline I am very attached to Xuefeng Mountain & 6.165 & 0.988 & 0.804 & \\
\hline Xuefeng Mountain means a lot to me & 6.000 & 0.940 & 0.777 & \\
\hline I identify strongly with Xuefeng Mountain & 5.858 & 1.032 & 0.805 & \\
\hline I feel Xuefeng Mountain is a part of me & 5.648 & 0.972 & 0.697 & \\
\hline Pro-tourism behaviors & & & & 0.788 \\
\hline \multicolumn{5}{|l|}{ I would: } \\
\hline $\begin{array}{l}\text { receive tourists as affable host and being more } \\
\text { hospitable }\end{array}$ & 6.354 & 0.988 & 0.723 & \\
\hline protect the natural resources on which tourism depends & 6.281 & 0.816 & 0.843 & \\
\hline $\begin{array}{l}\text { provide information to tourists and raise their } \\
\text { experience }\end{array}$ & 6.073 & 0.920 & 0.839 & \\
\hline $\begin{array}{l}\text { contribute to promoting Xuefeng Mountain as tourist } \\
\text { destinations }\end{array}$ & 5.832 & 1.001 & 0.683 & \\
\hline $\begin{array}{l}\text { accept some inconvenience for gaining tourism } \\
\text { development benefits }\end{array}$ & 5.328 & 1.351 & 0.618 & \\
\hline
\end{tabular}

Table 3. Descriptive statistics and correlation matrix.

\begin{tabular}{lcccccccc}
\hline \multicolumn{1}{c}{ Variables } & M & SD & CR & AVE & $\mathbf{1}$ & $\mathbf{2}$ & $\mathbf{3}$ \\
\hline $\begin{array}{l}\text { 1. Destination social } \\
\text { responsibility }\end{array}$ & 5.891 & 0.728 & 0.837 & 0.507 & $\mathbf{0 . 7 1 2}$ & & & \\
2. Place dependence & 5.739 & 0.836 & 0.816 & 0.526 & $0.437^{* * *}$ & $\mathbf{0 . 7 2 5}$ & $\mathbf{0 . 7 7 2}$ & \\
3. Place identity & 5.918 & 0.812 & 0.855 & 0.596 & $0.519^{* * *}$ & $0.611^{* * *}$ & $\mathbf{0 . 7 4 5}$ \\
4. Pro-tourism behaviors & 5.974 & 0.759 & 0.860 & 0.555 & $0.445^{* * *}$ & $0.519^{* * *}$ & $0.592^{* * *}$ & $\mathbf{0 . 7 4 5}$ \\
\hline
\end{tabular}

Note: M: mean; SD: standard deviation; CR: composite reliability; AVE: average variance extracted. Correlations are below the diagonal, and the square root values of the AVEs of the variables are provided in bold on the diagonal. *** $p<0.001$.

\subsubsection{Validity Testing}

Construct validity was checked according to convergent and discriminant validity. Convergent validity was concluded to be satisfactory because all standardized factor loadings exceeded 0.600 (see 
Table 2), and all were statistically significant $(p<0.001)$. Moreover, the average variance extracted (AVE) was evaluated to estimate convergent validity. As presented in Table 3, all AVEs of the four constructs ranged from 0.507 to 0.596 , exceeding the suggested 0.50 [57] and indicating a high level of convergent validity. Discriminant validity was then examined by comparing the square root of AVE with the correlation coefficient between factors. The square roots of AVEs (ranging from 0.712 to 0.772 ) were all higher than any paired factor correlation values, which provides good evidence of discriminant validity [57].

\subsection{Structural Model and Hypotheses Testing}

\subsubsection{Structural Model Indices}

After the reliability and validity of all constructs were checked on the basis of the CFA results, the structural equation modeling (SEM) was conducted to test the adequacy of the structural model. The fitting indices of the structural model $\left(X^{2}=267.642, \mathrm{df}=108, p<0.001, X^{2} / \mathrm{df}=2.478, \mathrm{TLI}=0.931\right.$, CFI $=0.951$, SRMR $=0.052$, RMSEA $=0.062$ ) demonstrated satisfactory overall fit of the proposed model to the data [58].

\subsubsection{Hypotheses Testing}

This research also tested the direct effects in the model depicted in Table 4. Hypothesis 1 predicts that destination social responsibility is positively associated with pro-tourism behaviors of residents. As Table 4 shows, destination social responsibility demonstrated a significantly positive association with pro-tourism behaviors of residents ( $\beta=0.152, p<0.001,95 \% \mathrm{CI}[0.061,0.244]$ ). Hypothesis 2 and Hypothesis 3 predict that destination social responsibility is positively associated with place dependence and place identity of residents. The structural equation modeling results provided evidence for Hypothesis 2 and Hypothesis 3 on this significantly positive impact of destination social responsibility on place dependence and place identity $(\beta=0.437, p<0.001,95 \% \mathrm{CI}[0.360,0.514] ; \beta=$ $0.519, p<0.001,95 \%$ CI [0.450, 0.587], respectively). In summary, our study found empirical support for Hypothesis 1, Hypothesis 2, and Hypothesis 3. This study further investigated the mediating effect of place dependence and place identity, as described in the next section.

Table 4. Hypothesis testing results.

\begin{tabular}{|c|c|c|c|c|c|}
\hline Hypothesized Paths & Hypothesis & $\beta$ & $p$-Value & $95 \%$ CI & Supported \\
\hline $\begin{array}{c}\text { Destination social } \\
\text { responsibility } \rightarrow \\
\text { Pro-tourism behaviors }\end{array}$ & $\mathrm{H}_{1}$ & $0.152 * * *$ & 0.000 & {$[0.061,0.244]$} & Yes \\
\hline $\begin{array}{l}\text { Destination social } \\
\text { responsibility } \rightarrow \text { Place } \\
\text { dependence }\end{array}$ & $\mathrm{H}_{2}$ & $0.437^{* * *}$ & 0.000 & {$[0.360,0.514]$} & Yes \\
\hline $\begin{array}{l}\text { Destination social } \\
\text { responsibility } \rightarrow \text { Place } \\
\text { identity }\end{array}$ & $\mathrm{H}_{3}$ & $0.519^{* * *}$ & 0.000 & {$[0.450,0.587]$} & Yes \\
\hline $\begin{array}{c}\text { Place identity } \rightarrow \\
\text { Pro-tourism behaviors }\end{array}$ & I & $0.377^{* * *}$ & 0.000 & {$[0.276,0.478]$} & l \\
\hline $\begin{array}{l}\text { Place dependence } \rightarrow \\
\text { Pro-tourism behaviors }\end{array}$ & / & $0.222 * * *$ & 0.000 & {$[0.124,0.320]$} & l \\
\hline
\end{tabular}

\subsection{Mediation Testing}

To estimate the extent to which place dependence and place identity explained the indirect relationship between destination social responsibility and pro-tourism behaviors of residents, our study conducted Sobel tests [53] and bootstrapping tests [54]. As described in Table 5, significant Z values of the Sobel tests (Destination social responsibility $\rightarrow$ Place dependence $\rightarrow$ Pro-tourism behaviors for $6.349^{* * *}$; Destination social responsibility $\rightarrow$ Place identity $\rightarrow$ Pro-tourism behaviors for $7.804^{* * *}$ ) 
indicated that the link between destination social responsibility and pro-tourism behaviors of residents was mediated by place dependence and place identity. The mediation effects of place dependence and place identity were statistically significant, with approximately $39.4 \%$ and $57.5 \%$ of the total effect being mediated. Moreover, since the $95 \%$ percentile-based confidence intervals for the indirect effects did not contain zero ([0.105, 0.260] for place dependence; $[0.168,0.366]$ for place identity) (see Table 5), bootstrapping testing results confirmed the mediating effect of place dependence and place identity. Therefore, hypothesis 4 and 5 were supported, which predict that place dependence and place identity partially mediate the influence of destination social responsibility on pro-tourism behaviors of residents.

Table 5. Mediation testing of place attachment.

\begin{tabular}{cccccccc}
\hline \multirow{2}{*}{ Mediation Paths } & Hypothesis & Indirect & & Sobel Test & \multicolumn{2}{c}{ Bootstrapping } \\
\cline { 5 - 7 } & & Effects & & Percentile 95\% CI \\
\cline { 5 - 7 } & & & & SE & Lower & Upper \\
\hline $\begin{array}{c}\text { Destination social responsibility } \rightarrow \text { Place } \\
\text { dependence } \rightarrow \text { Pro-tourism behaviors } \\
\text { Destination social responsibility } \rightarrow \text { Place } \\
\text { identity } \rightarrow \text { Pro-tourism behaviors }\end{array}$ & $\mathrm{H}_{4}$ & 0.183 & 0.029 & $\begin{array}{c}6.349 \\
* * *\end{array}$ & 0.105 & 0.260 \\
\hline
\end{tabular}

Note: ${ }^{* * *} p<0.001$. SE: standard error; CI: confidence interval.

\section{Discussion and Implications}

\subsection{Conclusions}

This study integrated the perspectives of CSR and tourism literature streams and the place attachment theory by focusing on how destination social responsibility affects residents' pro-tourism behaviors. To the best of our knowledge, this is the first study that developed and tested a mediation model that links destination social responsibility, place attachment, and pro-tourism behaviors of residents in the tourism industry. The testing of the structural equation model in our study indicates that destination social responsibility exerts a significantly positive impact on place dependence, place identity, and pro-tourism behaviors of residents. Furthermore, the testing of the mediation model also demonstrates that place dependence and place identity partially mediate the relationship between destination social responsibility and pro-tourism behaviors of residents. This study contributes to the place attachment theory and sustainable tourism literature and extends previous studies that depict micro-level, resident-associated outcomes of social responsibility in various ways.

\subsection{Theoretical Implications}

First, the findings of our study contribute to the sustainable tourism and CSR literature by providing an addition to the conventional line of antecedents to residents' pro-tourism behaviors, which are considered to ensure sustainability in tourism planning and development, even maybe a precondition for sustainable tourism. Our study is among the first to develop and test a model that links destination social responsibility and the pro-tourism behaviors of residents in the tourism context, which expands the nomological network of residents' pro-tourism behaviors.

Second, our mediation model of place attachment expands the understanding of the linkages for resident-associated outcomes and their antecedents by suggesting that both place dependence and identity can serve as a route through which destination social responsibility is related to pro-tourism behaviors. Previous studies have provided some different mechanisms that mediate the effects of resident-associated outcomes and their antecedents [11,14]. However, the extant tourism research has paid inadequate attention to exploring the people-place bonding mechanism. The mediation model in our study provides a new understanding of the psychological mechanism linking residents' pro-tourism behavior and its antecedents. 
Finally, unlike previous studies focusing on social exchange theory $[11,14,15]$, our research diverts from the conventional social exchange perspective of treating pro-tourism behaviors as attempts to maximize positive tourism impact to propose that pro-tourism behaviors can also be a manifestation of psychological bonding between residents and their meaningful environments. Therefore, the findings of our research provide a novel theoretical perspective digging into the antecedents of resident-associated outcomes in the tourism industry and enrich the theoretical boundary of place attachment theory.

\subsection{Managerial Implications}

Managerially, our research provides important guidelines for strategic and operational management practices for both tourism companies and governments to motivate residents to develop pro-tourism behaviors. It is suggested to integrate destination social responsibility initiatives with sustainability practices to foster positive resident-associated outcomes. Specifically, there are several managerial implications for tourism companies and administrations in tourism sustainable development.

Destination social responsibility, a critical issue in the dialogue among administrations, tourism companies, and community residents, turns out to be a "win-win" situation for all stakeholders within the destination [16]. As for administrations, to achieve sustainable tourism development, destination tourism governments can provide supportive policies and access to encourage tourism companies to engage in social responsibility initiatives. Moreover, it is essential for tourism companies to invest in social responsibility initiatives and programs, which have been proven to be effective strategies to foster the pro-tourism behaviors of residents. In fact, a large number of tourism companies now try to leverage their social responsibility actions, such as ecological environment protection, participation in corporate philanthropy, pro-poor tourism, targeted poverty alleviation, etc., because more and more tourism companies are convinced that destination social responsibility involvement and engagement are not merely the "right thing to do" but as well "the smart thing to do".

In the search for social responsibility levers to motivate residents' pro-tourism behaviors, the current study also realizes that destination social responsibility is not an across-the-board solution. In particular, the findings of our study indicate that destination social responsibility can impact pro-tourism behaviors of residents, but to the extent that destination social responsibility fosters both the functional bonds and affective connections with the particular community, destination, or environment. Hence, to cultivate the linkages between destination social responsibility initiatives and pro-tourism behaviors of residents within the destination, social responsibility initiatives and programs should be tailored to allow for positive perception and even active involvement of residents to activate the people-place emotional connections and meanings.

\subsection{Limitations and Future Research}

There are several limitations in our research that could be considered for future research. First, our study conducted a self-administered survey to obtain data from a single source and adopted cross-sectional research. This might not accurately reflect actual pro-tourism behavior and overestimate the relationship. Although procedural remedies and multiple statistical controls showed a lack of common method bias, we suggest further studies could use multiple data sources to provide a more robust approach. Second, our research merely investigated the mediation model linking residents' pro-tourism behaviors to its antecedents; therefore, additional insight could be derived from applying our model across boundary conditions and mechanisms to have a systematic investigation of their interactive effects. Finally, the measurement of residents' pro-tourism behaviors was adapted from previous literature, and this scale might be limited to behavioral intentions, therefore, the items for actual behaviors of residents' pro-tourism need to be included in the future measurement. 
Author Contributions: Conceptualization, B.H. and J.L.; Methodology, B.H.; Software, B.H.; Validation, B.H.; Formal Analysis, B.H.; Investigation, Y.T.; Resources, J.L.; Data Curation, Y.T.; Writing-Original Draft Preparation, B.H. and J.L.; Writing-Review \& Editing, B.H. and J.L.; Visualization, B.H.; Supervision, B.H. and J.L.; Project Administration, B.H.; Funding Acquisition, B.H.

Funding: This research was funded by the National Natural Science Foundation of China (No. 71802080), Research Foundation of Education Bureau of Hunan Province, China (No. 17B174), China Scholarship Council.

Conflicts of Interest: The authors declare no conflict of interest.

\section{References}

1. Litvin, S.W.; Goldsmith, R.E.; Pan, B. Electronic word-of-mouth in hospitality and tourism management. Tour. Manag. 2008, 29, 458-468. [CrossRef]

2. Sautter, E.T.; Leisen, B. Managing stakeholders a Tourism Planning Model. Ann. Tour. Res. 1999, 26, 312-328. [CrossRef]

3. Henderson, J.C. Corporate social responsibility and tourism: Hotel companies in Phuket, Thailand, after the Indian Ocean tsunami. Int. J. Hosp. Manag. 2007, 26, 228-239. [CrossRef]

4. Chen, N.; Dwyer, L. Residents' Place Satisfaction and Place Attachment on Destination Brand-Building Behaviors: Conceptual and Empirical Differentiation. J. Travel Res. 2018, 57, 1026-1041. [CrossRef]

5. Sharpley, R. Host perceptions of tourism: A review of the research. Tour. Manag. 2014, 42, 37-49. [CrossRef]

6. Stylidis, D.; Terzidou, M. Tourism and the economic crisis in Kavala, Greece. Ann. Tour. Res. 2014, 44, 210-226. [CrossRef]

7. Gursoy, D.; Chi, C.G.; Dyer, P. Locals' Attitudes toward Mass and Alternative Tourism: The Case of Sunshine Coast, Australia. J. Travel Res. 2010, 49, 381-394. [CrossRef]

8. Strzelecka, M.; Boley, B.B.; Strzelecka, C. Empowerment and resident support for tourism in rural Central and Eastern Europe (CEE): The case of Pomerania, Poland. J. Sustain. Tour. 2017, 25, 554-572. [CrossRef]

9. Peters, M.; Chan, C.-S.; Legerer, A. Local Perception of Impact-Attitudes-Actions towards Tourism Development in the Urlaubsregion Murtal in Austria. Sustainability 2018, 10, 2360. [CrossRef]

10. Su, L.; Huang, S.; Pearce, J. Toward a model of destination resident-environment relationship: The case of Gulangyu, China. J. Travel Tour. Mark. 2019, 36, 469-483. [CrossRef]

11. Su, L.; Huang, S.; Huang, J. Effects of Destination Social Responsibility and Tourism Impacts on Residents' Support for Tourism and Perceived Quality of Life. J. Hosp. Tour. Res. 2016, 42, 1039-1057. [CrossRef]

12. Stronza, A.; Pêgas, F. Ecotourism and conservation: Two cases from Brazil and Peru. Hum. Dimens. Wildl. 2008, 13, 263-279. [CrossRef]

13. Poudel, S.; Nyaupane, G.P.; Budruk, M. Stakeholders' Perspectives of Sustainable Tourism Development:A New Approach to Measuring Outcomes. J. Travel Res. 2016, 55, 465-480. [CrossRef]

14. Ribeiro, M.A.; Pinto, P.; Silva, J.A.; Woosnam, K.M. Residents' attitudes and the adoption of pro-tourism behaviours: The case of developing island countries. Tour. Manag. 2017, 61, 523-537. [CrossRef]

15. Eusébio, C.; Vieira, A.L.; Lima, S. Place attachment, host-tourist interactions, and residents' attitudes towards tourism development: The case of Boa Vista Island in Cape Verde. J. Sustain. Tour. 2018, 26, 890-909. [CrossRef]

16. Su, L.; Huang, S.; Pearce, J. How does destination social responsibility contribute to environmentally responsible behaviour? A destination resident perspective. J. Bus. Res. 2018, 86, 179-189. [CrossRef]

17. Korschun, D.; Bhattacharya, C.B.; Swain, S.D. Corporate social responsibility, customer orientation, and the job performance of frontline employees. J. Mark. 2014, 78, 20-37. [CrossRef]

18. McWilliams, A.; Siegel, D. Corporate social responsibility: A theory of the firm perspective. Acad. Manag. Rev. 2001, 26, 117-127. [CrossRef]

19. Lee, S.; Seo, K.; Sharma, A. Corporate social responsibility and firm performance in the airline industry: The moderating role of oil prices. Tour. Manag. 2013, 38, 20-30. [CrossRef]

20. Font, X.; Guix, M.; Bonilla-Priego, M.J. Corporate social responsibility in cruising: Using materiality analysis to create shared value. Tour. Manag. 2016, 53, 175-186. [CrossRef]

21. Youn, H.; Hua, N.; Lee, S. Does size matter? Corporate social responsibility and firm performance in the restaurant industry. Int. J. Hosp. Manag. 2015, 51, 127-134. [CrossRef] 
22. Park, S.; Song, S.; Lee, S. Corporate social responsibility and systematic risk of restaurant firms: The moderating role of geographical diversification. Tour. Manag. 2017, 59, 610-620. [CrossRef]

23. Kim, B.; Lee, S.; Kang, K.H. The moderating role of CEO narcissism on the relationship between uncertainty avoidance and CSR. Tour. Manag. 2018, 67, 203-213. [CrossRef]

24. Lee, C.-K.; Song, H.-J.; Lee, H.-M.; Lee, S.; Bernhard, B.J. The impact of CSR on casino employees' organizational trust, job satisfaction, and customer orientation: An empirical examination of responsible gambling strategies. Int. J. Hosp. Manag. 2013, 33, 406-415. [CrossRef]

25. Youn, H.; Lee, K.; Lee, S. Effects of corporate social responsibility on employees in the casino industry. Tour. Manag. 2018, 68, 328-335. [CrossRef]

26. Supanti, D.; Butcher, K. Is corporate social responsibility (CSR) participation the pathway to foster meaningful work and helping behavior for millennials? Int. J. Hosp. Manag. 2019, 77, 8-18. [CrossRef]

27. Su, L.; Swanson, S.R. Perceived corporate social responsibility's impact on the well-being and supportive green behaviors of hotel employees: The mediating role of the employee-corporate relationship. Tour. Manag. 2019, 72, 437-450. [CrossRef]

28. Inoue, Y.; Lee, S. Effects of different dimensions of corporate social responsibility on corporate financial performance in tourism-related industries. Tour. Manag. 2011, 32, 790-804. [CrossRef]

29. Theodoulidis, B.; Diaz, D.; Crotto, F.; Rancati, E. Exploring corporate social responsibility and financial performance through stakeholder theory in the tourism industries. Tour. Manag. 2017, 62, 173-188. [CrossRef]

30. Freeman, R.E. Strategic Management: A Stakeholder Perspective; Piman: Boston, MA, USA, 1984.

31. Su, L.; Huang, Y. How does Perceived Destination Social Responsibility Impact Revisit Intentions: The Mediating Roles of Destination Preference and Relationship Quality. Sustainability 2019, 11, 133. [CrossRef]

32. Li, Y.; Liu, B.; Huan, T.-C. Renewal or not? Consumer response to a renewed corporate social responsibility strategy: Evidence from the coffee shop industry. Tour. Manag. 2019, 72, 170-179. [CrossRef]

33. Kyle, G.; Graefe, A.; Manning, R. Testing the Dimensionality of Place Attachment in Recreational Settings. Environ. Behav. 2005, 37, 153-177. [CrossRef]

34. Morgan, P. Towards a developmental theory of place attachment. J. Environ. Psychol. 2010, 30, 11-22. [CrossRef]

35. Lewicka, M. Place attachment: How far have we come in the last 40 years? J. Environ. Psychol. 2011, 31, 207-230. [CrossRef]

36. Devine-Wright, P. Explaining "NIMBY" Objections to a Power Line: The Role of Personal, Place Attachment and Project-Related Factors. Environ. Behav. 2013, 45, 761-781. [CrossRef]

37. Williams, D.R.; Vaske, J.J. The Measurement of Place Attachment: Validity and Generalizability of a Psychometric Approach. For. Sci. 2003, 49, 830-840.

38. Yuksel, A.; Yuksel, F.; Bilim, Y. Destination attachment: Effects on customer satisfaction and cognitive, affective and conative loyalty. Tour. Manag. 2010, 31, 274-284. [CrossRef]

39. Anton, C.E.; Lawrence, C. The relationship between place attachment, the theory of planned behaviour and residents' response to place change. J. Environ. Psychol. 2016, 47, 145-154. [CrossRef]

40. Kelly, S.; Bricker, D.L.K. Level of Specialization and Place Attachment: An Exploratory Study of Whitewater Recreationists. Leis. Sci. 2000, 22, 233-257.

41. Brown, G.; Raymond, C. The relationship between place attachment and landscape values: Toward mapping place attachment. Appl. Geogr. 2007, 27, 89-111. [CrossRef]

42. Raymond, C.M.; Brown, G.; Weber, D. The measurement of place attachment: Personal, community, and environmental connections. J. Environ. Psychol. 2010, 30, 422-434. [CrossRef]

43. Proshansky, H.M.; Fabian, A.K.; Kaminoff, R. Place-identity: Physical world socialization of the self. J. Environ. Psychol. 1983, 3, 57-83. [CrossRef]

44. Vaske, J.J.; Kobrin, K.C. Place Attachment and Environmentally Responsible Behavior. J. Environ. Educ. 2001, 32, 16-21. [CrossRef]

45. Beery, T.; Jönsson, K.I. Outdoor recreation and place attachment: Exploring the potential of outdoor recreation within a UNESCO Biosphere Reserve. J. Outdoor Recreat. Tour. 2017, 17, 54-63. [CrossRef]

46. Kamalipour, H.; Yeganeh, A.J.; Alalhesabi, M. Predictors of Place Attachment in Urban Residential Environments: A Residential Complex Case Study. Procedia Soc. Behav. Sci. 2012, 35, 459-467. [CrossRef]

47. Brown, B.; Perkins, D.D.; Brown, G. Place attachment in a revitalizing neighborhood: Individual and block levels of analysis. J. Environ. Psychol. 2003, 23, 259-271. [CrossRef] 
48. Gu, H.; Ryan, C. Place attachment, identity and community impacts of tourism-The case of a Beijing hutong. Tour. Manag. 2008, 29, 637-647. [CrossRef]

49. Nunkoo, R.; Gursoy, D. Residents' support for tourism: An Identity Perspective. Ann. Tour. Res. 2012, 39, 243-268. [CrossRef]

50. Wang, S.; Chen, J.S. The influence of place identity on perceived tourism impacts. Ann. Tour. Res. 2015, 52, 16-28. [CrossRef]

51. Strzelecka, M.; Boley, B.B.; Woosnam, K.M. Place attachment and empowerment: Do residents need to be attached to be empowered? Ann. Tour. Res. 2017, 66, 61-73. [CrossRef]

52. Schaffer, B.S.; Riordan, C.M. A review of cross-cultural methodologies for organizational research: A best-practices approach. Organ. Res. Methods 2003, 6, 169-215. [CrossRef]

53. Sobel, M.E. Asymptotic confidence intervals for indirect effects in structural equation models. Sociol. Methodol. 1982, 13, 290-312. [CrossRef]

54. Preacher, K.J.; Hayes, A.F. Asymptotic and resampling strategies for assessing and comparing indirect effects in multiple mediator models. Behav. Res. Methods 2008, 40, 879-891. [CrossRef] [PubMed]

55. Podsakoff, P.M.; MacKenzie, S.B.; Podsakoff, N.P. Sources of method bias in social science research and recommendations on how to control it. Ann. Rev. Psychol. 2012, 63, 539-569. [CrossRef] [PubMed]

56. Hair, J.; Black, W.; Babin, B.; Anderson, R. Multivariate Data Analysis, 7th ed.; Prentice Hall: Upper Saddle River, NJ, USA, 2009.

57. Fornell, C.; Larcker, D.F. Structural Equation Models with Unobservable Variables and Measurement Error: Algebra and Statistics. J. Mark. Res. 1981, 18, 382-388. [CrossRef]

58. Hu, L.T.; Bentler, P.M. Cutoff criteria for fit indexes in covariance structure analysis: Conventional criteria versus new alternatives. Struct. Equ. Model. Multidiscip. J. 1999, 6, 1-55. [CrossRef]

(C) 2019 by the authors. Licensee MDPI, Basel, Switzerland. This article is an open access article distributed under the terms and conditions of the Creative Commons Attribution (CC BY) license (http://creativecommons.org/licenses/by/4.0/). 